Vol. 1, No. 4, 2019

\title{
PENGEMBANGAN MODUL IPA FISIKA BERBASIS PBL PADA POKOK BAHASAN GERAK LURUS UNTUK MENINGKATKAN KEMAMPUAN BERPIKIR KRITIS SISWA
}

\author{
Sabina Yasriyani Lawut ${ }^{1}$, Maris Kurniawati ${ }^{2}$, Hestiningtyas Yuli Pratiwi ${ }^{3}$ \\ Program Studi Pendidikan Fisika, Universitas Kanjuruhan Malang ${ }^{1,2,3}$ \\ e-mail : yasriinatar.95@gmail.com
}

\begin{abstract}
Abstrak. Penelitian ini bertujuan untuk mengetahui kelayakan modul IPA Fisika berbasis PBL pada pokok bahasan Gerak Lurus yang dikembangkan dan keefektifan modul yang dikembangkan dalam meningkatkan kemampuan berpikir kritis siswa. Metode yang diterapkan Research and Development. Uji coba produk dilakukan di salah satu SMP PGRI di Kabupaten Malang. Hasil penelitian menunjukkan bahwa penilaian modul IPA terpadu berbasis PBL oleh ahli materi memperoleh rata-rata persentase $77,6 \%$ dengan kriteria layak, ahli media memperoleh rata-rata persentase 93,33\%. Pada uji coba skala kecil, modul yang dikembangkan mendapat rata-rata persentase skor $88 \%$ dengan respon sangat baik oleh siswa. Hasil uji coba skala besar menunjukkan bahwa modul yang dikembangkan dalam kegiatan pembelajaran mendapat rata-rata persentase skor $88,90 \%$ dan guru memperoleh rata-rata persentase 93,12\% dengan respon sangat baik oleh guru. Modul IPA Fisika berbasis Problem Based Learning efektif dalam meningkatkan kemampuan berpikir kritis siswa. Berdasarkan hasil analisis menunjukkan adanya peningkatan secara keseluruhan hasil tes kemampuan berpikir kritis siswa sesuai dengan indikator kemampuan berpikir kritis adalah sebagai berikut: (1) Memberikan penjelasan sederhana memperoleh peningkatan sebesar 0,661 dengan kriteria "sedang", dimana nilai untuk kategori sedang yaitu $0,3<\mathrm{g}<0,7$. (2)Membangun keterampilan dasar memperoleh peningkatan sebesar 0,832 dengan kriteria "tinggi", dimana nilai untuk kriteria "tinggi" g>0,7. (3) Menyimpulkan memperoleh peningkatan sebesar 0,941 dengan kriteria "tinggi". (4) Memberikan penjelasan lanjut memperoleh peningkatan sebesar 0,834 dengan kriteria "tinggi". (5) Mengatur strategi dan taktik memperoleh peningkatan sebesar 0,499 dengan kriteria "sedang”. Berdasarkan hasil analisis, skor total rata-rata untuk peningkatan hasil tes kemampuan berpikir kritis siswa adalah 0,7534 dengan kriteria "tinggi”, dimana nilai untuk kriteria "tinggi” yaitu g<0,7.
\end{abstract}

Kata Kunci : Modul IPA Fisika; Problem Based Learning; Berpikir Kritis

\section{PENDAHULUAN}

Fisika adalah bagian dari sains (IPA), pada hakikatnya IPA sebagai kumpulan pengetahuan dapat berupa fakta, konsep, prinsip, hukum, teori, dan model yang biasa disebut produk selain itu yang paling penting dalam IPA adalah proses dalam pembelajaran (Trianto, 2007). Siswa dalam mempelajari pengetahuan IPA Fisika diperlukan kontak langsung dengan objek yang ingin diketahui, sehingga pelajaran IPA Fisika di sekolah diharapkan dapat menjadi wahana bagi siswa untuk mempelajari diri sendiri dan alam sekitar (Yuliani dkk.,2011). Pelajaran IPA Fisika merupakan pelajaran yang kurang disenangi oleh sebagian besar siswa dengan alasan bahwa belajar IPA Fisika adalah aktivitas yang tidak menyenangkan karena Fisika sangat sulit dipahami dan seringkali disajikan dengan persamaan matematik, sehingga banyak anak yang menganggap bahwa Fisika terlalu banyak rumus (Saira, 2015).

Berdasarkan hasil wawancara lisan dengan guru bidang studi IPA Fisika di salah satu SMP PGRI di Kabupaten Malang dan siswa yang telah mempelajari mata pelajaran IPA Fisika di kelas VIII, pembelajaran IPA Fisika sampai saat ini masih menggunakan buku-buku atau bahan ajar cetak konvensional. Pendidik hanya menggunakan sebuah buku sebagai satu-satunya bahan ajar. Bahan ajar cetak tersebut hanya berisi ringkasan materi, contoh soal dan latihan- 
latihan soal dalam pembelajaran IPA Fisika. Strategi pengorganisasian dan penyampaian isi di dalam bahan ajar tersebut tidak terstruktur dengan baik dan kemasannya sangat tidak menarik. Hal ini diduga sebagai salah satu penyebab rendahnya hasil belajar IPA Fisika peserta didik kelas VIII di salah satu SMP PGRI di Kabupaten Malang.

Pengembangan modul dapat menjawab atau memecahkan masalah ataupun kesulitan dalam belajar (Depdiknas, 2008). Terdapat sejumlah materi pembelajaran yang seringkali peserta didik sulit untuk memahaminya ataupun pendidik sulit untuk menjelaskannya. Kesulitan tersebut dapat saja terjadi karena materi tersebut abstrak, rumit, dan asing. Pembelajaran IPA fisika yang dilaksanakan oleh guru-guru IPA Fisika selama ini kurang mengaktifkan siswa sehingga menyebabkan siswa pasif dalam pembelajaran, hal itu menyebabkan kemampuan berpikir kritis siswa dalam memahami materi IPA Fisika belum dimaksimalkan (Trianto, 2007). Solusi dari hal tersebut maka pembelajaran harus dikemas dalam sebuah model pembelajaran yang menarik dan mengembangkan keterampilan berpikir siswa (Sujiono \& Arif, 2014). Salah satu model pembelajaran yang dapat dijadikan alternatif pilihan adalah model pembelajaran problem based learning (PBL) (Rusman, 2012).

Problem Based Learning (PBL) merupakan salah satu pendekatan pembelajaran yang digunakan untuk merangsang berpikir tingkat tinggi siswa dalam situasi yang berorientasi pada masalah dunia nyata (Rusman, 2012).Penggunaan modul dalam pembelajaran IPA fisika berbasis PBL diharapkan dapat membantu siswa dalam meningkatkan penguasaan dengan mempelajari tujuan, ringkasan materi, latihan terstruktur, latihan yang harus dipecahkan, dan kunci jawaban. Melalui modul IPA Fisika ini siswa dapat belajar lebih banyak, meningkatkan keterampilan memecahkan soal melalui latihan, menilai sendiri hasil pekerjaan yang telah dilakukan. Salah satu materi dalam pembelajaran IPA Fisika adalah Gerak Lurus.

Berdasarkan hasil penelitian awal siswa kelas VIII di salah satu SMP PGRI di Kabupaten Malang, bahwa siswa tertarik materi IPA Fisika pada pokok bahasan gerak lurus dikemas dalam sebuah modul untuk memudahkan siswa dalam memahami materi gerak lurus dengan persentase $79 \%$. Pada pokok bahasan gerak lurus, masih banyak siswa yang mengalami kesulitan tentang penerapan gerak lurus dalam kehidupan sehari-hari, maka perlu dirancang bahan ajar yang menarik dan sistematis. Berdasarkan uarian-uraian dan beberapa pendapat di atas, peneliti tertarik untuk mengadakan penelitian yang berjudul, "Pengembangan Modul IPA Fisika Berbasis PBL Untuk Meningkatkan Berpikir Kritis Siswa Pada Pokok Bahasan Gerak Lurus.

\section{METODE PENELITIAN}

Penelitian ini dilaksanakan di salah satu SMP PGRI di Kabupaten Malang. Jenis penelitian yang digunakan yaitu Research and Development yang berarti suatu metode penelitian untuk menghasilkan suatu produk tertentu atau mengembangkan produk dan diuji keefektifannya (Sugiyono, 2010). Penelitian R \& D ini meliputi beberapa tahapan yaitu: identifikasi masalah, pengumpulan data, desain produk, validasi desain oleh ahli, uji coba skala kecil, revisi produk, uji coba skala besar, revisi produk, produk akhir, dan uji coba pelaksanaan lapangan.Populasi penelitian adalahseluruh siswa kelas VIII. Teknik analisis data yang dilakukan meliputi: (1) analisis soal instrumen, (2) analisis kelayakan produk oleh para ahli yang meliputi ahli bidang materi, ahli media dan ahli bahasa, (3) analisis angket tanggapan guru dan siswa, dan (4) analisis keefektifan modul dengan N-gain ternormalisasi pada nilai pretest dan posttest serta ketuntasan hasil belajar siswa.

\section{HASIL DAN PEMBAHASAN}

Modul pembelajaran IPA Terpadu yang telah dikembangkan divalidasikan oleh pakar untuk melihat kelayakan modul tersebut. Prosedur pengembangan dalam penelitian ini menggunakan metode penelitian pengembangan Borg and Gall, dengan lebih sederhana melibatkan 5 (lima) langkah utama yaitu: (1) Melakukan analisis produk yang akan dikembangkan, (2) mengembangkan produk awal, (3) validasi ahli dan revisi, (4) uji coba lapangan skala kecil dan revisi produk, (5) uji coba lapangan skala besar dan produk akhir.

Hasil pengujian tahap I dan revisi I dilakukan berdasarkan penilaian dari para ahli dan guru. Analisis kelayakan modul dilakukan oleh ahli materi, ahli media dan guru IPA Fisika 
SMP berupa skor penilaian, kritik dan saran yang membangun sebagai bahan pertimbangan untuk melakukan revisi agar diperoleh produk yang lebih baik.

Penilaian tahap I berdasarkan penilaian dari ahli materi, ahli media, dan guru IPA Fisika SMP dapat dilihat pada Tabel 1.

Tabel 1. Hasil penilaian ahli materi, ahli media, dan guru IPA Fisika SMP

\begin{tabular}{llll}
\hline No. & Validator & Rerata Skor & Total \\
\hline 1. & Ahli materi & 3,10 & Baik \\
\hline 2. & Ahli media & 3,73 & Sangat baik \\
\hline 3. & Guru IPA Fisika SMP & 3,725 & Sangat baik \\
\hline
\end{tabular}

Modul yang dikembangkan dikatakan layak dengan alasan bahwa modul sudah melewati beberapa serangkaian prosedur penyusunan modul pembelajaran. Prosedur tersebut adalah melakukan analisis produk yangakan dikembangkan, mengembangkan produk, validasi ahli dan revisi, uji coba lapangan skala kecil dan uji coba lapangan skala besar. Tahap penilaian oleh guru SMP menggunakan angket untuk menialai bagaimana tingkat kelayakan modul. Kelayakan modul juga dilihat dari hasil angket tanggapan siswa. Angket tanggapan siswa disajikan pada Tabel 2. Modul IPA terpadu berbasis PBL berdasarkan penilaian pakar dan dinyatakan layak selanjutnya dilakukan uji coba dalam skala kecil dengan jumlah responden 6 siswa dan skala besar dengan responden sejumlah 20 orang siswa. Selain itu pada tahap uji pelaksanaan lapangan juga diberikan angket kepada siswa.

Tabel 2. Rekapitulasi Hasil Penilaian Angket Siswa Pada Skala Kecil dan Skala Besar

\begin{tabular}{|c|c|c|c|}
\hline No & Aspek Yang Dinilai & Skala kecil & Skala besar \\
\hline 1 & Ketertarikan siswa untuk mempelajari modul & $\begin{array}{l}95 \% \quad \text { (sangat } \\
\text { baik) }\end{array}$ & $\begin{array}{l}87.5 \% \\
\text { (sangat baik) }\end{array}$ \\
\hline 2 & Petunjuk penggunaan modul dapat dipahami siswa & $\begin{array}{l}87 \% \\
\text { (sangat baik) }\end{array}$ & $\begin{array}{l}82.5 \% \\
\text { (sangat baik) }\end{array}$ \\
\hline 3 & Bahasa yang digunakan sudah baik & $\begin{array}{l}91 \% \\
\text { (sangat baik) }\end{array}$ & $\begin{array}{l}92.5 \% \\
\text { (sangat baik) }\end{array}$ \\
\hline 4 & $\begin{array}{l}\text { Petunjuk percobaan sederhana dalam modul dapat } \\
\text { dipahami siswa }\end{array}$ & $\begin{array}{l}87 \% \\
\text { (sangat baik) }\end{array}$ & $\begin{array}{l}91.25 \% \\
\text { (sangat baik) }\end{array}$ \\
\hline 5 & $\begin{array}{l}\text { Penyajian masalah dalam modul IPA Fisika berbasis } \\
\text { PBL pada pokok bahasan gerak lurus membuat tertarik } \\
\text { untuk mempelajari materi. }\end{array}$ & $\begin{array}{l}83 \% \\
\text { (sangat baik) }\end{array}$ & $\begin{array}{l}85 \% \\
\text { (sangat baik) }\end{array}$ \\
\hline 6. & $\begin{array}{l}\text { Kemampuan berpikir kritis siswa dengan menggunakan } \\
\text { modul }\end{array}$ & $\begin{array}{l}87 \% \\
\text { (sangat baik) }\end{array}$ & $\begin{array}{l}87.5 \% \\
\text { (sangat baik) }\end{array}$ \\
\hline 7. & $\begin{array}{l}\text { Aktivitas belajar siswa menggunakan modul yang } \\
\text { dikembangkan }\end{array}$ & $\begin{array}{l}87 \% \\
\text { (sangat baik) }\end{array}$ & $\begin{array}{l}92.5 \% \\
\text { (sangat baik) }\end{array}$ \\
\hline 8. & $\begin{array}{l}\text { Modul IPA Fisika berbasis PBL digunakan untuk materi } \\
\text { IPA Fisika lain yang sesuai }\end{array}$ & $\begin{array}{l}87 \% \\
\text { (sangat baik) }\end{array}$ & $\begin{array}{l}92.5 \% \\
\text { (sangat baik) }\end{array}$ \\
\hline & Rata-rata persentase yang diperoleh & $\begin{array}{l}88 \%, \\
\text { (sangat baik) }\end{array}$ & $\begin{array}{l}88,90 \%, \\
\text { (sangat baik) }\end{array}$ \\
\hline
\end{tabular}

Tahap ujicoba skala kecil hasil angket yang diberikan pada siswa memperoleh rata-rata persentase $88 \%$ dengan kriteria sangat baik Siswa beranggapan modul IPA Fisika berbasis PBL menarik dan menarik minat mereka untuk mempelajari modul. Siswa menilai bahasa yang digunakan dalam modul mudah dipahami, selain itu mereka antusias ketika diberikan modul untuk dipelajari dan kemudian diminta mengisi angket. Para siswa setuju modul yang dikembangkan membuat siswa tertarik untuk mempelajari modul IPA Fisika pada pokok bahasan gerak lurus. Tanggapan dari siswa dengan pembelajaran menggunakan modul IPA Fisika yang dikembangkan dapat memberikan pengalaman belajar baru dengan modul yang 
menggunakan model PBL. Hal ini karena siswa jarang untuk dilibatkan dalam pembelajaran IPA Fisika yang lebih mengaktifkan siswa.

Modul IPA Fisika memperoleh tanggapan positif dari siswa, sehingga modul IPA Fisika yang dikembangkan dapat digunakan pada ujicoba skala besar. Uji coba skala besar dilakukan pada kelas VIII C dengan jumlah siswa 20. Hasil yang positif juga diperoleh pada tahap ujicoba skala besar dimana rata-rata persentase skor yang diperoleh yaitu $88,90 \%$. Hal ini menunjukkan modul yang dikembangkan membuat minat siswa untuk mempelajari modul baik. Siswa juga menilai petunjuk penggunaan modul dan bahasa dalam modul mudah untuk dipahami. Siswa antusias bertanya tentang karakteristik model PBL, sehingga peneliti memberikan penjelasan yang lebih kepada siswa tentang model PBL. Penelitian ini selain untuk mengetahui kelayakan modul yang dikembangkan juga dimaksudkan untuk mengetahui keefektifan modul IPA Fisika berbasis PBL dalam meningkatkan kemampuan berpikir kritis siswa kelas VIII SMP PGRI 2 Lawang . Uji pelaksanaan lapangan dilaksanakan di kelas VIII C PGRI 2 Lawang dengan jumlah siswa sebanyak 20 siswa. Hasil yang diperoleh disajikan pada Tabel.3.

Tabel 3. Rekapitulasi Hasil Uji N-gain Data Nilai Hasil Pretest dan Posttest

\begin{tabular}{llllll}
\hline \multirow{2}{*}{ No } & Indikator berpikir kritis & \multicolumn{2}{l}{ Rata-rata skor } & \multirow{2}{*}{$\begin{array}{l}\text { Nilai } \\
\text { gain }\end{array}$} & N- kriteria \\
\cline { 3 - 4 } & & Pretest & Posttest & & \\
\hline 1 & Memberikan Penjelasan Sederhana & 48,75 & 84,375 & 0,661 & Sedang \\
\hline 2 & Membangun Keterampilan Dasar & 31,25 & 88,75 & 0,832 & Tinggi \\
\hline 3 & Menyimpulkan & 57,5 & 96,25 & 0,941 & Tinggi \\
\hline 4 & Memberikan Penjelasan Lanjut & 54,375 & 91,875 & 0,834 & Tinggi \\
\hline 5 & Mengatur Strategi dan Taktik & $\mathbf{5 4 , 3 7 5}$ & $\mathbf{7 9 , 3 7 5}$ & 0,499 & Sedang \\
\hline Rata-rata & $\mathbf{4 9 , 2 5}$ & $\mathbf{8 8 , 1 2 5}$ & $\mathbf{0 , 7 5 3 4}$ & \\
\hline Kriteria & Tinggi & & & \\
\hline
\end{tabular}

Hasil penelitian menunjukkan adanya peningkatan secara keseluruhan hasil tes kemampuan berpikir kritis siswa antara pretest dan posttest, yaitu perbedaan hasil tes siswa sebelum dan sesudah diterapkannya pembelajaran dengan menggunakan modul IPA Fisika berbasis Problem Based Learnging yang dikembangkan. Berdasarkan hasil analisis menunjukkan adanya peningkatan secara keseluruhan hasil tes kemampuan berpikir kritis siswa sesuai dengan indikator kemampuan berpikir kritis adalah sebagai berikut: (1) Memberikan penjelasan sederhana memperoleh peningkatan sebesar 0,661 dengan kriteria "sedang", dimana nilai untuk kategori sedang yaitu 0,3<g<0,7. (2) Membangun keterampilan dasar memperoleh peningkatan sebesar 0,832 dengan kriteria "tinggi", dimana nilai untuk kriteria "tinggi" g>0,7. (3) Menyimpulkan memperoleh peningkatan sebesar 0,941 dengan kriteria "tinggi". (4) Memberikan penjelasan lanjut memperoleh peningkatan sebesar 0,834 dengan kriteria "tinggi". (5) Mengatur strategi dan taktik memperoleh peningkatan sebesar 0,499 dengan kriteria "sedang". Berdasarkan hasil analisis, skor total rata-rata untuk peningkatan hasil tes kemampuan berpikir kritis siswa adalah 0,7534 dengan kriteria "tinggi", dimana nilai untuk kriteria "tinggi" yaitu g>0,7.

\section{KESIMPULAN}

Berdasarkan hasil penelitian, dapat disimpulkan bahwa modul IPA Fisika berbasis PBL pada pokok bahasan gerak lurus yang dikembangkan layak digunakan berdasarkan penilaian dari pakar. Modul IPA Fisika berbasis PBL yang dikembangkan efektif meningkatkan kemampuan berpikir kritis siswa. Saran yang dapat disampaikan berdasarkan penelitian ini adalah beberapa siswa kurang memahami model PBL, sehingga sebelum pembelajaran dilaksanakan siswa dijelaskan karakteristik model PBL dan langkah-langkah pembelajaran agar pembelajaran lebih efektif. 


\section{DAFTAR RUJUKAN}

Aida, T. N. 2014. Pengembangan Modul Bimbingan Keterampilan Asertif Untuk Siswa SMP. Skripsi Tidak Diterbitkan: Universitas Kanjuruhan Malang.

Andreas, S. 2011. Penerapan pengajaran kontekstual berbasis masalah untuk meningkatkahn hasil belajar biologi peserta didik kelas X2 SMA Laboratorium Singaraja. Jurnal Penelitian dan Pengem bangan Pendidikan. 2(1). 45-59.

Arikunto, S. 2009. Dasar-Dasar Evaluasi Pendidikan. Jakarta: Bumi Aksara.

BSNP. 2007. Buletin BSNP Kapal Itu Bernama UN. Jakarta: BSNP

Daryanto. 2013. Menyusun Modul.Yogyakarta: Vega Media.

Depdiknas. 2008. Panduan pengembangan bahan ajar. Dirjen Dikdasmen Direktorat Pembinaan SMA.

Efriana, A.T., Haryani, S., \& Sedyawati, S.M.R. 2013. Pengembangan Modul IPA Terpadu Berkarakter Tema Pengelolaan Lingkungan Untuk Kelas VII Smp. Unnes Science Education Journal 2 (2): 269-273.

Kristaningsih, N. 2013. Pengembangan Modul Untuk Meningkatkan Self Esteem Siswa SMP Kelas VII. Skripsi tidak diterbitkan. Malang: program sarjana universitas kanjuruhan malang.

Kuswandari, M. 2013. Pengembangan Bahan Ajar Fisika SMA Dengan Pendekatan Kontekstual Pada Materi Pengukuran Besaran Fisika. Jurnal Pendidikan Fisika (2013) Vol.1 No.2.

Lydi, A.F., Eko.S. K. \& Nur. N. 2013. Pengembangan Modul Fisika Pada Pokok Bahasan Listrik Dinamis Berbasis Domain Pengetahuan Sains Untuk Mengoptimalkan Minds-On Siswa SMA Negeri 2 Purworejo Kelas X Tahun Pelajaran 2012/2013. Radiasi, Vol.3 No.1

Listyawati, M. 2012. Pengembangan Perangkat Pembelajaran IPA Terpadu di SMP. Journal Of Innovative Science Education. 1(1): 61-69.

Mustaji. 2009. Pengembangan Kemampuan Berpikir Kritis Dan Kreatif Dalam Pembelajaran. Diakses dari Http://Pasca. Tp. Ac. Id/Site/Pengembangan-Kemampuan-BerpikirKritis-Dan-Kreatif-Dalam-Pembelajaran. Diakses 10 Januari 2014.

Norkotib, M. 2010. Pengaruh Model Pembelajaran Kreatif-Produktif terhadap Prestasi Belajar ditinjau dari Kemampuan Berpikir Kritis Siswa Kelas X Program RSBI di SMAN 1 Blitar. Malang. Tesis Program Pascasarjana Universitas Negeri Malang.

Parmin. 2012. Pengembangan Modul Mata Kuliah Strategi Belajar Mengajar IPA Berbasis Hasil Penelitian Pembelajaran. Jurnal Pendidikan IPA Indonesia 1 (1): 8-15.

Parmin \& Sudarmin. 2013. IPA Terpadu. Semarang: Cv Swadaya.

Peraturan Menteri Pendidikan Nasional Republik Indonesia. 2006. Peraturan Menteri Pendidikan Nasional Republik Indonesia Nomor 22 Tahun 2006 Tentang Standar Isi Untuk Satuan Pendidikan Dasar Dan Menengah. 
Peraturan Menteri Pendidikan Nasional Republik Indonesia. 2006. Peraturan Menteri Pendidikan Nasional Republik Indonesia Nomor 24 Tahun 2006 Tentang Pelaksanaan Peraturan Menteri Pendidikan Nasional Repubrik Indonesia Nomor 22 Tahun 2006 Tentang Standar Isi Untuk Satuan Pendidikan Dasar Dan Menengah Dan Peraturan Menteri Pendidikan Nasional Repubrik Indonesia Nomor 23 Tahun 2006 Tentang Standar Kompetensi Lulusan Untuk Satuan Pendidikan Dasar Dan Menengah.

Prastowo, A. 2012. Panduan Kreatif Membuat Bahan Ajar Inovatif. Yogyakarta: Diva Press.

Purwanto, R. \& Lasmono. 2007. Pengembangan Modul. Jakarta:Depdiknas.

Raharjo, S. 2011. Pengaruh model pembelajaran kontekstual terhadap hasil belajar kimia ditinjau dari motivasi berprestasi: Studi eksperimen pada peserta didik kelas XI IPA SMA Negeri 1 Kuta. Tesis (Tidak dipublikasikan). Singaraja: Program Pasca Sarjana Universitas Pendidikan Ganesha.

Ratnawati, D.I. 2013. Pengembangan Modul Peningkatan Rasa Percaya Diri Bagi Siswa SMP Kelas VII. Skripsi tidak diterbitkan. Malang: Program Sarjana Universitas Kanjuruhan Malang.

Rosnawati, R. 2009. Enam Tahapan Aktivitas Dalam Pembelajaran Matematika Untuk Mendayagunakan Berpikir Tingkat Tinggi Siswa. Prosiding Seminar Nasional. Yogyakarta: Universitas Negeri Yogyakarta.

Rusman. 2012. Model-Model Pembelajaran. Jakarta: Raja Grafindo Persada.

Savery, J. 2006. Overview Of Problem Based Learning: Definitions And Distinctions. Interdisciplinary Of Journal Problem Based Learning 1(1): 8-20.

Saira S.,\& Johri S. 2015. Pengembangan buku ajar fisika untuk meningkatkan motivasi belajar siswa kelas VII SMPN 20 Mataram tahun pelajaran 2014/2015. Jurnal fisika dan pendidikan fisika. 1(1).1-9.

Santyasa, I. W. 2009. Metode penelitian pengembangan dan teori pengembangan modul. Makalah disajikan dalam pelatihan bagi para pendidik TK, SD, SMP, SMA, dan SMK tanggal 12-14 Januari 2009, di Kecamatan Nusa Penida Kabupaten Klungkung.

Setyorini, U., Sukiswo, S.E. \& Subali, B. 2011. Penerapan Model Problem Based Learning Untuk Meningkatkan Kemampuan Berpikir Kritis Siswa SMP. Jurnal Pendidikan Fisika Indonesia. 7(1):52-56.

Sri, J. U. 2015. Pengembangan Media Pembelajaran Fisika Berupa Kartun Animasi Pada Pokok Bahasan Termodinamika Untuk Siswa SMK Kelas XI. Skripsi tidak diterbitkan. Malang: Program Sarjana Universitas Kanjuruhan Malang.

Sudijono A. 2004. Pengantar Statistik Pendidikan. Jakarta: Raja Grafindo Persada.

Sugiyono. 2010. Metode Penelitian Kuantitatif, Kualitatif, dan R\&D. Bandung: Alfabeta.

Sujiono \& Arif. 2014. Pengembangan Modul IPA Terpadu Berbasis Problem Based Learning Tema Gerak Untuk Meningkatkan Kemampuan Berpikir Kritis Siswa. Unnes Science Education Journal. 3(3).

Suparno. 20007. Metodologi Pembelajaran Fisika. Jogjakarta, Universitas Sanata Dharma. 
Susilo, A.B., Wiyanto, \& Supartono. 2012. Model Pembelajaran IPA Berbasis Masalah Untuk Meningkatkan Motivasi Belajar Dan Berpikir Kritis Siswa SMP. Unnes Science Education Journal 1 (1):13-20.

Suyono, D. N. \& Nadi, S. 2009. Pengembangan Perangkat Pembelajaran IPA Terpadu SMP Berpola Connected. Artikel Surabaya: Universitas Negeri Surabaya.

Trianto. 2007. Model-Model Pembelajaran Inovatif Berorientasi Konstruktivistik. Jakarta: Prestasi Pustaka.

Trianto. 2012. Model Pembelajaran Terpadu Konsep, Srategi, Dan Implementasinya Dalam KTSP. Jakarta: Bumi Aksara.

Vembrianto. 1985. Pengantar Pengajaran Modul. Yogyakarta: Yayasan Pendidikan Paramita.

Walker, G. H., 2005. Critical Thinking in Asynchronous Discussions. International Journal Technology and Distance Learning, 2(6): 19-21.

Wartono. 2007. Evaluasi pendidikan. Malang.

Wena \& Made. 2010. Strategi Pembelajaran Inovatif Kontemporen: Suatu Tinjauan Konseptual Operasional. Jakarta: Bumi Aksara.

Wilujeng, I. 2011. IPA Terpadu. Materi Disampaikan Dalam Rangka Stadium General Program Studi Pendidikan IPA Tanggal 19 Mei 2011 Di Universitas Negeri Semarang

Yuliani, H., Sunarno W. \& Suparmi. Jurnal inkuiri . 2012. Pembelajaran Fisika Dengan Pendekatan Ketrampilan Proses Dengan Metode Eksperimen Dan Demonstrasi Ditinjau Dari Sikap Ilmiah dan Kemampuan Analisis. ISSN: 2252-7893 Vol 1 No.3, 2012. 